\title{
Effect of Dexamethasone on B7 Regulation and T Cell Activation in Neonates and Adults
}

\author{
THORSTEN W. ORLIKOWSKY, GÜNTHER E. DANNECKER, BÄRBEL SPRING, \\ MARTIN EICHNER, MICHAEL K. HOFFMANN, AND CHRISTIAN F. POETS \\ University Children's Hospital [T.W.O., B.S., C.F.P.], 72070 Tuebingen, Germany; Olgahospital [G.E.D.], \\ 70176 Stuttgart, Germany; Department of Medical Biometry [M.E.], 72070 Tuebingen, Germany; and \\ Department of Immunology and Microbiology [M.K.H.], New York Medical College, Valhalla,
} New York 10595

\begin{abstract}
The safety of dexamethasone for neonates has been questioned, partly because of its multiple unspecific effects on the immune system. Specific effects of dexamethasone on costimulatory and immune suppressive functions of neonatal compared with adult macrophages (MФ) are not known. We evaluated the effect of dexamethasone on the expression and regulation of $\mathrm{M} \Phi$ B7 family receptors (B7-1, CD80; B7-2, CD86) and on their ability to co-stimulate T cells. Cord blood macrophages (CBM $\Phi)$ and $\mathrm{M} \Phi$ from healthy adults (PBM $\Phi)$ were isolated, and cell surface markers were phenotyped by flow cytometry. In tissue culture, cells were exposed to dexamethasone, interferon- $\gamma($ IFN- $\gamma)$, cAMP, or a T cell mitogen $(\alpha \mathrm{CD} 3)$ and examined for their capacity to activate or destroy $\mathrm{T}$ cells. CВM $\Phi$ were less able to up-regulate CD80 and CD86 than PBM $\Phi(p<0.05)$. Dexamethasone inhibited the up-regulation of CD80, CD86, and HLA-DR on PBM $\Phi$ and even more so on CВMФ $(p<0.05$ versus PBM $\Phi$ for CD80 and CD86). In the presence of dexamethasone, stimulation with $\alpha \mathrm{CD} 3 \mathrm{MAb}$ enhanced cytotoxic functions of PMBM $\Phi$ and increase in deleted $\mathrm{T}$ cells, a reduced fraction of enlarged $\mathrm{T}$ cells,
\end{abstract}

Preterm newborns have been exposed to dexamethasone for the prevention or treatment of bronchopulmonary dysplasia (BPD) for many years $(1,2)$. Dexamethasone is a synthetic glucocorticoid that reduces the recruitment of inflammatory cells $(3,4)$ and thereby is thought to inhibit the development of BPD. Its effects on other developing organs such as the CNS were only recognized much later. Because follow up-studies provided evidence of abnormal neurodevelopment, early postnatal use of dexamethasone is not recommended any more (2). Nevertheless, glucocorticoids continue to be given to pregnant women to accelerate fetal lung development.

Received September 17, 2003; accepted September 22, 2004.

Correspondence: Thorsten W. Orlikowsky, M.D., Univ.-Kinderklinik Tübingen, Germany, Calwerstrasse 7, 72076 Tübingen; e-mail: thorsten.orlikowsky@med.uni-tuebingen.de.

DOI: 10.1203/01.PDR.0000156211.48307.F5 and an inhibition of T cell CD28 up-regulation, which again were more pronounced with $\mathrm{CBM} \Phi(p<0.05$ versus $\mathrm{PBM} \Phi)$. In conclusion, neonatal $\mathrm{M} \Phi$ are exquisitely sensitive to the inhibitory effects of dexamethasone on B7 expression. Although perhaps producing the desired therapeutic effect, dexamethasone may do so in newborns at the expense of a near complete paralysis of $\mathrm{M} \Phi$-dependent $\mathrm{T}$ cell function. (Pediatr Res 57: 656-661, 2005)

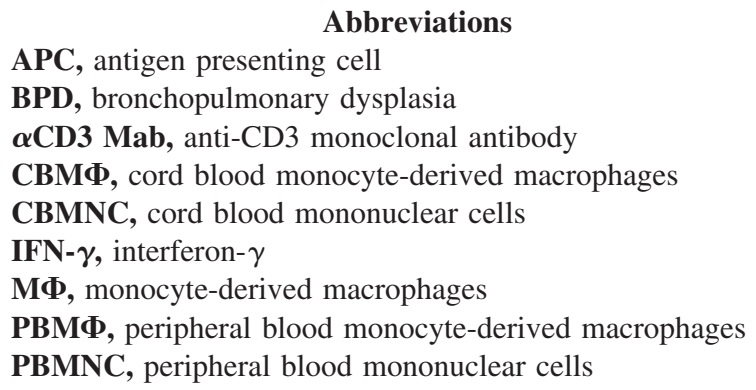

Besides the endocrinium, the primary target of dexamethasone is the immune system, which is incompletely developed in neonates. Evidence that the immunosuppressive effects of dexamethasone are primarily mediated via an inhibition of cytokine production has been produced. Mononuclear cells from adults and neonates respond differently to treatment with dexamethasone. With respect to proinflammatory cytokines, cord blood cells show an increased sensitivity toward the inhibitory action of dexamethasone compared with cells from adult donors, resulting in a more pronounced inhibition of IL-1 $\beta$, IL-6, tumor necrosis factor- $\alpha$, IL-12, IL-2, and IL-3 production $(5,6)$.

Dexamethasone may directly inhibit $\mathrm{T}$ cell proliferation (7), induce apoptosis (8), promote long-lasting changes in the $\mathrm{T}$ cell receptor $\mathrm{v} \beta$ repertoire (9), or decrease the $\mathrm{CD} 4 / \mathrm{CD} 8$ ratio in infants with BPD (10). Dexamethasone also influences gene expression of cytokines and various functions of antigen pre- 
senting cells (APC), including B cells, dendritic cells, and monocytes/macrophages (11-13).

$\mathrm{T}$ cell activation in the neonate is impaired (7). Beside intrinsic $\mathrm{T}$ cell deficiencies, their reduced capacity to become activated largely results from an impaired function of and interaction with APC (14-16). The ability of APC, including monocyte-derived macrophages $(\mathrm{M} \Phi)$, to induce costimulatory signals in $\mathrm{T}$ cells by engaging their $\mathrm{CD} 28$ receptors is critically important for the $\mathrm{T}$ cell response. The lack of co-stimulation leads to anergy or apoptosis of antigen-reactive $\mathrm{T}$ cells $(17,18)$. The CD28 ligands are expressed on $M \Phi$ and belong to the B7 receptor family. Beyond controlling T cell activation and cell death, B7 ligation influences $\mathrm{T}$ cell differentiation and cytokine production (19).

In humans, the B7 family consists of at least two molecules, B7-1 (CD80) and B7-2 (CD86), which belong to the immunoglobulin superfamily (20). Both bind to ligands on $\mathrm{T}$ cells, CD28, and CTLA4 (CD152) (21,22). The B7/CD28 family consists of additional receptors, each of which may promote activating or terminating signals (reviewed in 22).

CD86 (B7-2) is constitutively expressed on MФ (21). The up-regulation of CD80 and CD86 occurs after contact with nominal antigen, IFN- $\gamma$ (23), lipopolysaccharide (24), or mitogen-activated $\mathrm{T}$ cells (25) with different kinetics (26). In adult donors, glucocorticoids were found to inhibit the activation-induced expression of B7 receptors in $\mathrm{M} \Phi$ (27).

Cord blood macrophages (CBM $\Phi)$ per se exhibit a reduced co-stimulatory potential: CD80 and CD86 expression and upregulation are significantly inhibited in CВМФ compared with $M \Phi$ from adult donors (16). Consistent with this observation, $\mathrm{M} \Phi$-dependent $\mathrm{T}$ cell activation is reduced in neonates, and CВM $\Phi$ preferentially deliver negative signals to T cells (16).

In view of the immaturity of the neonatal immune system, we were interested in investigating the capacity of neonatal $\mathrm{M} \Phi$ to respond to dexamethasone. To our knowledge, its impact on neonatal $\mathrm{M} \Phi$ and on $\mathrm{M} \Phi$-dependent $\mathrm{T}$ cell reactions has not yet been studied. Because mechanisms that control B7 receptors bear large consequence for the $\mathrm{T}$ cell response, we tested the hypothesis that sensitivity toward dexamethasone-induced inhibition of B7 expression and on $\mathrm{T}$ cell proliferation compared with

\section{METHODS}

Patients. The study protocol was approved by the Ethics Committee of the University of Tuebingen. All mothers gave written consent before they went into labor. Randomly selected, unrelated adult healthy volunteers donated blood and served as control subjects. All term neonates were delivered spontaneously and did not exhibit signs of infection, as defined by the clinical status, white blood cell count, and C-reactive protein. Mothers with amnion infections and prolonged labor were excluded. Umbilical cord blood was drawn from the fetal side of the placenta by puncture with a sterile needle, attached to a syringe without suction, and placed in heparin-coated tubes (100 $\mathrm{IE} / \mathrm{mL}$ blood) immediately after ligation of the cord.

Cell cultures. Peripheral blood (PBMCs) and cord blood mononuclear cells (CBMNC) were isolated by Ficoll-Hypaque (Pharmacia LKB, Uppsala, Sweden) density gradient centrifugation. Washed cells were resuspended in RPMI 1640 (Sigma Chemical Co., St. Louis, MO) that contained 10\% FCS (Sigma Chemical Co.) and incubated at $37^{\circ} \mathrm{C}$ in a humidified incubator with a $5 \% \mathrm{CO}_{2}$ atmosphere.

Preparation of mononuclear cell subsets. Unseparated mononuclear cells were placed at $3 \times 10^{5}$ cells $/ 0.1 \mathrm{~mL}$ in flat-bottom 96 -well microtiter plates (Falcon, Bedford, MA). For separating macrophages from lymphocytes, cells were plated at $3 \times 10^{6}$ cells per $1.5 \mathrm{~mL}$ in $60 \times 15$-mm culture vessels (NoK4-3802-4; Becton Dickinson, Mountain View, CA) in the incubator and allowed to adhere for $60 \mathrm{~min}$. Nonadherent cells were gently removed by repeatedly pipetting $500 \mu \mathrm{L}$ of RPMI buffer into the cultures. Remaining adherent cells were washed thoroughly twice and used as a source of macrophages. Usually, $85 \%$ of adherent cells expressed CD14.

For further eliminating contaminating nonadherent macrophages, the procedure above described was repeated with the fraction of nonadherent cells. Usually, $<1 \% \mathrm{CD} 14^{+}$macrophages were found in the nonadherent fraction after this adherence cycle, as determined by FACS analysis.

Co-culture Experiments. Macrophage-enriched adherent cells $\left(1 \times 10^{5} /\right.$ $0.05 \mathrm{~mL})$ and macrophage-depleted nonadherent cells were mixed $(2 \times$ $10^{5} / 0.05 \mathrm{~mL}$ ). Nonadherent cell fractions were not pooled from different donors. For equalizing allogeneic effects, СВМФ and РВМФ of one adult donor were co-cultured with nonadherent cells of a second adult donor.

Flow cytometry. A daily calibrated FACScan flow cytometer (Becton Dickinson) was used to perform phenotypic analysis. For preventing nonspecific binding, cells were incubated with 10\% human serum on ice for $10 \mathrm{~min}$ before staining with FITC-, phycoerythrin-, or isotype-specific Ig-labeled MAb for 20 min over ice in the dark. $М \Phi$ were gated by forward, side scatter, and CD14 expression. For ensuring that larger cells were $М \Phi$ recently migrated and not lymphoblasts, a parallel analysis was performed with the MAb anti-CD3 (SK7). Dead lymphocytes were discriminated by propidium iodide (Molecular Probes, Eugene, OR; $5 \mu \mathrm{g} / \mathrm{mL}, 5 \mathrm{~min}$ ). Propidium iodide-negative cells were counted and analyzed for expression of CD4 and CD8. T cell blasts were detected as $\mathrm{CD} 4^{+}$or $\mathrm{CD} 8^{\mathrm{hi}+}$ cells with enlarged size in the forward scatter as previously described (28).

Reagents. Human recombinant IFN- $\gamma$, a potent inducer of CD80 and CD86 (15), was purchased from R\&D Systems (Minneapolis, MN). Cell-permeable dibutyryl-cAMP, up-regulating the expression of CD86 but not of CD80 on МФ (27), was obtained from Sigma Chemical Co.

Fresh dilutions of dexamethasone (Sigma Chemical Co.) in PBS solutions were prepared for each experiment and added at concentrations from $10^{-9}$ to $10^{-4}$ mol shortly before addition of B7-inducing substances. Serum concentrations to $10^{-5} \mathrm{~mol}$ may be reached pharmacologically (5). Cultures that were incubated in the absence of dexamethasone served as controls. The $\mathrm{T}$ cell mitogen anti-CD3 MAb (OKT3, $1 \mu \mathrm{g} / \mathrm{mL})$ was purchased from Ortho Diagnostics (Raritan, NJ).

Antibodies to CD14 (MФР9), CD80 (L307.4), CD86 (IT2.2), HLA-DR (L243), CD3 (SK7), CD4 (SK3), CD8 (SK1), and CD28 (L293) and Igmatched controls (IgG1, IgG2b) were purchased from Becton Dickinson (Heidelberg, Germany). Tissue culture experiments were repeated at least three times. Results are expressed in mean \pm SD.

Data display and statistical analysis. Fluorescence intensities were determined, and the nonspecific background staining was subtracted. Statistical analysis was performed by using the decadic logarithm of the values of CD80, CD86, HLA-DR, and CD28. Using an ANOVA, we examined whether the variables were influenced by dexamethasone and age (both nominal effects). The variable "patient" (nominal) was nested under "age," and the nested variables were modeled as a random effect. Furthermore, an interaction between "age" and "dexamethasone" was considered.

Using an analysis of covariance (ANCOVA), we examined whether the decadic logarithm of numbers of resting or blast-forming $\mathrm{T}$ cells were influenced by time, the origin of the blood, and dexamethasone. The variable "patient" was nested and modeled as a random effect. Furthermore, an interaction between "patient" and "day" was considered. Values of $p<0.05$ were considered statistically significant. Statistical analysis was performed using the Sigmaplot 2000 software for Windows (SPSS, Chicago, IL).

\section{RESULTS}

Effect of dexamethasone on CD80, CD86, and HLA-DR expression. СВM $\Phi$ and $\mathrm{PBM} \Phi$ were incubated for $48 \mathrm{~h}$ with and without various concentrations of dexamethasone. Spontaneous and IFN- $\gamma$-induced CD80 and CD86 expressions were determined. For examining whether the IFN- $\gamma$-induced effect was specific for CD80 and CD86, HLA-DR densities were also detected. Representative histograms for CD80 expression on РВMФ (left) and СВM $\Phi$ (right) are depicted in Fig. 1.

CBM $\Phi$ spontaneously expressed CD80, CD86, and HLA-DR in lower densities than $\operatorname{PBM} \Phi(p<0.05$; Fig. 2). Dexamethasone further decreased CD80 and CD86 expression in both groups ( $p<0.05$ versus unstimulated control) but did 

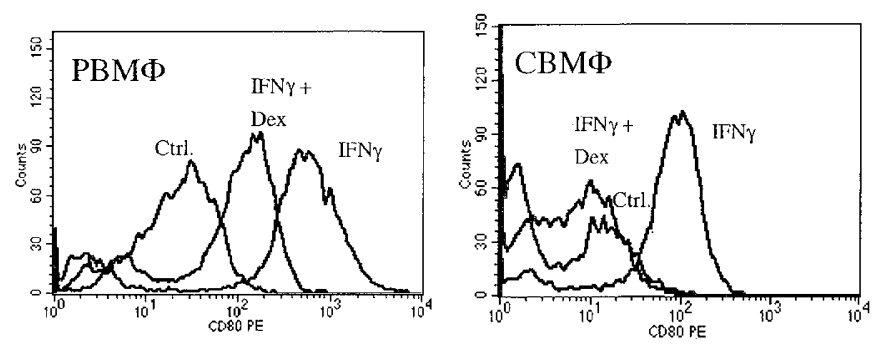

Figure 1. Dexamethasone inhibits IFN- $\gamma$-mediated CD80 up-regulation. PBMФ (left) and CBMФ (right) were cultured for $48 \mathrm{~h}$ in the absence or the presence of dexamethasone $\left(10^{-6} \mathrm{~mol}\right)$ and/or IFN- $\gamma(500 \mathrm{U} / \mathrm{mL})$. Histograms of one experiment were overlain; background staining was $<10^{1} \mathrm{MFI}$ (data not shown).

not influence the spontaneous HLA-DR expression. IFN- $\gamma$ caused an up-regulation of all three receptors and was more pronounced on $\operatorname{PBM} \Phi(p<0.05$ versus $\mathrm{CBM} \Phi)$.

Dexamethasone inhibited the IFN- $\gamma$-mediated up-regulation of CD80, CD86, and HLA-DR. On PBMФ, this inhibitory effect on CD80 and in both $\mathrm{M} \Phi$ populations the inhibition of HLA-DR expression were dose dependent. Dexamethasoneinduced CD80- and CD86-related effects were stronger on CВMФ $(p<0.01$ versus PBMФ); the inhibition of HLA-DR up-regulation did not differ significantly $(p=0.11)$. Survival, as detected by propidium iodide staining, was not affected by the drug (data not shown).

To investigate whether dexamethasone-mediated effects on CD80 and CD86 were restricted to IFN- $\gamma$, we used different B7 inducers (Fig. 3). Stimulation with cAMP did not affect CD80 expression (Fig. 3A) but resulted in increased CD86 receptor densities in both groups (Fig. $3 B$ ), with СВM $\Phi$ being less receptive ( $p<0.05$ versus PBM $\Phi)$. The addition of dexamethasone to this group inhibited CD86 up-regulation, again more pronounced on CВMФ $(p<0.05$ versus PBM $\Phi)$. The pattern seen with $\alpha \mathrm{CD} 3$ was similar to IFN- $\gamma$ stimulation with both: an impairment of CВMФ to up-regulate CD80 and CD86 and a stronger inhibitory effect of dexamethasone $(p<0.05$ versus РВMФ).

Effect of dexamethasone on MФ-dependent $\alpha C D 3-$ mediated $T$ cell reactions. In the presence or absence of dexamethasone, mononuclear cells from adults (PBMNC) or cord blood (CBMNC) were incubated with $\alpha \mathrm{CD} 3$. The frequencies of enlarged T cells (Fig. 4A) as a parameter of T cell activation, and the absolute numbers of viable $\mathrm{T}$ cells, a parameter of T cell survival (Fig. $4 B$ ), were assayed daily.

The fraction of enlarged $\mathrm{T}$ cells was increased in PBMNC $(p<0.05$ after 48 and $72 \mathrm{~h}$ versus CBMNC; Fig. $4 A$ ). In contrast, the fraction of $\mathrm{T}$ lymphocytes that were deleted before cells had a chance to divide was higher in CBMNC $(p<0.05$ versus $\mathrm{PBMNC}$ after $72 \mathrm{~h}$ ).

Dexamethasone enhanced the fraction of initially deleted $\mathrm{T}$ cells in cord blood ( $p<0.05$ versus $\alpha \mathrm{CD} 3$ and versus PBMNC) and inhibited $\mathrm{T}$ cell blast transformation in both groups $(p<0.05)$ but to a higher extent in CBMNC $(p<0.05$ versus PBMNC after $72 \mathrm{~h}$ ), consistent with the finding that the number of remaining $\mathrm{T}$ cells in this group was constantly decreasing.

For eliminating innate differences between neonatal and adult $\mathrm{T}$ cells, in particular their potentially different sensitivity toward dexamethasone, purified PBM $\Phi$ of one healthy adult donor, or CBM $\Phi$, were co-cultured with $М \Phi$-depleted nonadherent mononuclear cells of a second, unrelated healthy adult donor as a source of enriched T cells (Fig. 5).

CBM $\Phi$ diminished the fraction of proliferating T cells $(p<$ 0.05 versus $\mathrm{PBM} \Phi$ after 48 and 72 h; Fig. $5 A$ ) and enhanced the $\alpha \mathrm{CD} 3$-mediated deletion of adult T cells ( $p<0.05$ versus PBM $\Phi$ after 72 h; Fig. 5B). Treatment with dexamethasone essentially showed findings identical to those depicted in Fig. 4. In the presence of the decrease of remaining $\mathrm{T}$ cells and an almost abolished blast transformation ( $p<0.05$ versus Neither $M \Phi$-depleted enriched $\mathrm{T}$ cells nor $\mathrm{M} \Phi$-enriched adherent cells showed significant proliferation or deletion in the presence of $\alpha \mathrm{CD} 3(1 \mu \mathrm{g} / \mathrm{mL}$; data not shown). In the described interval, we found no differences with regard to proliferation between allogeneic $\mathrm{T}$ cells (data not shown). Co-incubation of lower numbers of $\mathrm{M} \Phi\left(5 \times 10^{-4} \mathrm{M} \Phi\right)$ with $\mathrm{T}$ cells had less effect in both cord and peripheral blood (data not shown), indicating the importance of the local tissue environment and $\mathrm{M} \Phi: \mathrm{T}$ cell ratio in vivo.

In the $\alpha \mathrm{CD} 3$-mediated reaction, engagement of B7 receptors with corresponding receptors on $\mathrm{T}$ cells leads to CD28 upregulation on $\mathrm{T}$ cells, which undergo blast transformation $(29,30)$. Using CВMФ as a source of co-stimulatory receptors, $\alpha \mathrm{CD} 3$-mediated CD28 up-regulation on T cells from healthy adult donors was impaired $(p<0.05$ versus PВМФ). Dexamethasone inhibited this $\alpha \mathrm{CD} 3$-mediated $\mathrm{CD} 28$ up-regulation in both groups but significantly more so in the presence of СВM $\Phi$ ( $p<0.05$ versus the $\mathrm{T}$ cell inhibiting impact of the drug to be mediated via co-stimulatory molecules on APC.

\section{DISCUSSION}

Our data identify the CD80 and CD86 receptors as targets of dexamethasone-induced immune suppression and show that neonatal M $\Phi$ exhibit an increased sensitivity toward this druginduced receptor inhibition. Functionally, this negatively influences the MФ-dependent T cell activation (Figs. 4 and 5, Table 1). In addition and in contrast to $P B M \Phi, C D 86$ expression on neonatal $\mathrm{M} \Phi$ is partially inhibited by the drug (Fig. $2 B$ ). Effects of dexamethasone on $\mathrm{M} \Phi$ are not restricted to CD80 and CD86, because HLA-DR expression is inhibited as well (Fig. 2B). Compared with $M \Phi$ from adults, neonatal $M \Phi$ already show a reduced potential to up-regulate CD80, CD86, and HLA-DR (16) (Figs. 2 and 3). Thereby, MФ-dependent T cell proliferation is inhibited in cord blood, and activationinduced cell death is promoted (Figs. 4 and 5).

$\mathrm{M} \Phi$ possess the capacity to regulate the $\mathrm{T}$ cell response positively and negatively. We distinguished two principal cytokine-induced $\mathrm{M} \Phi$ subsets. One, referred to as cytotoxic $\mathrm{M} \Phi$ (Mc) (31), lacks B7 expression (32) and is induced by IL-10 (33). The second subset, referred to as helper $\mathrm{M} \Phi$ (Mh) (31), is induced by IFN- $\gamma$ and expresses CD80, CD86, or both. Disturbances in the $\mathrm{Mh} / \mathrm{Mc}$ balance have been reported in various diseases (34-38). M $\Phi$ that express B7 family mole- 
A

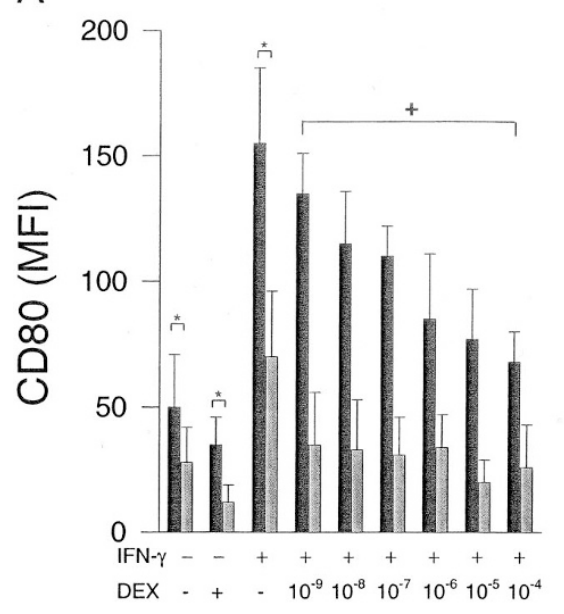

B

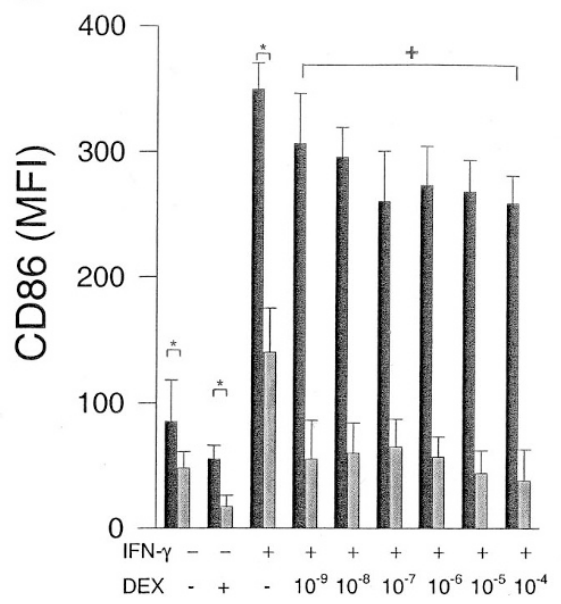

C

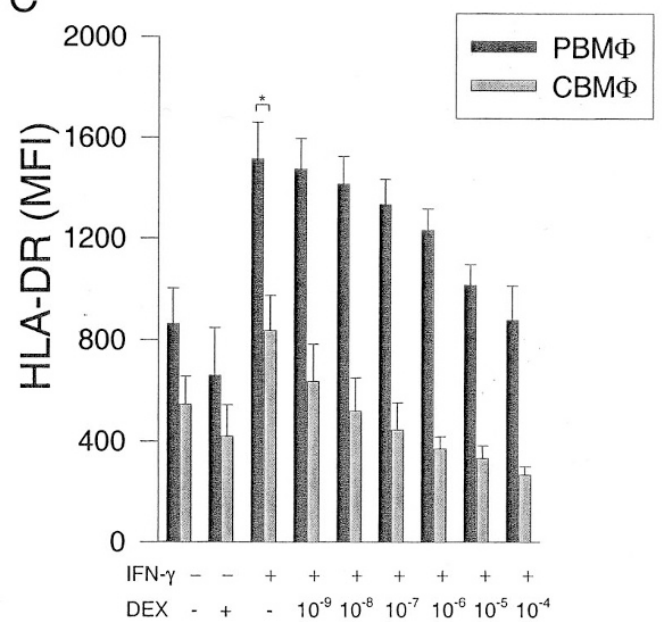

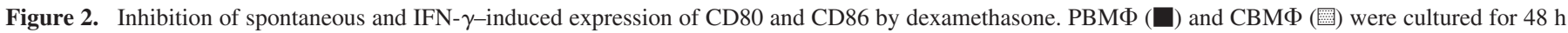

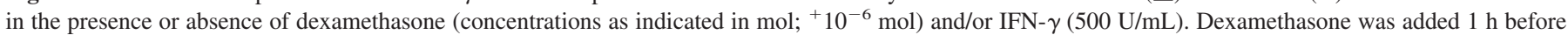

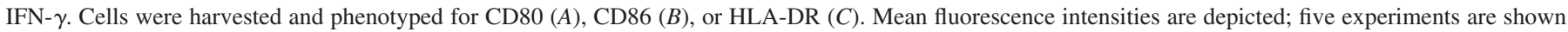

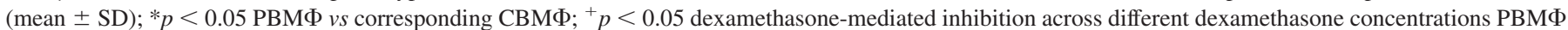
vs CВMФ.

A

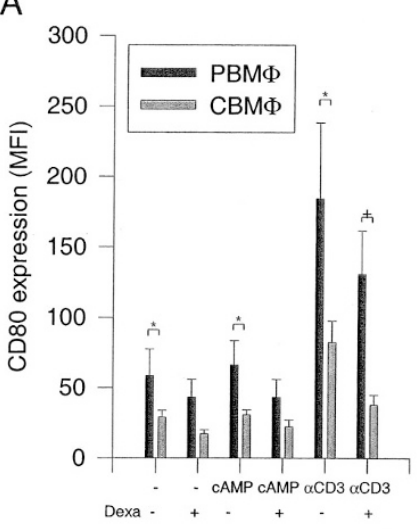

B

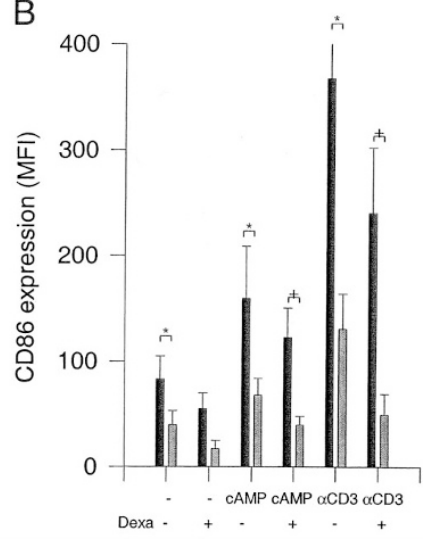

Figure 3. Dexamethasone-induced inhibition of cAMP- and $\alpha \mathrm{CD} 3$-induced B7 expression. Mononuclear cells $\left(2 \times 10^{5} / 0.1 \mathrm{~mL}\right)$ from healthy adults ( $\square$ ) and cord blood (罪) were cultured for $48 \mathrm{~h}$ alone or in the presence of cAMP $\left(10^{-3} \mathrm{~mol}\right)$ or $\alpha \mathrm{CD} 3(1 \mu \mathrm{g} / \mathrm{mL})$. Three groups received dexamethasone $\left(10^{-6}\right.$ $\mathrm{mol})$. Cells were harvested and phenotyped in triplicate for the mean fluorescence expression of CD80 $(A)$ or CD86 $(B)$. Five experiments are shown (mean $\pm \mathrm{SD}) .{ }^{*} p<0.05 \mathrm{PBM} \Phi$ vs corresponding $\mathrm{CBM} \Phi ;{ }^{+} p<0.05$ dexamethasone-mediated inhibition

cules induce neither $\mathrm{T}$ cell anergy nor $\mathrm{T}$ cell destruction by apoptosis, because both reactions are blocked in the presence of co-stimulation (28-30,39-41). М $\Phi$ that lack CD80 and CD86 expression are incapable of preventing the induction of anergy or apoptosis in conjugated $\mathrm{T}$ cells and act as negative immune regulators (42-44). In addition, МФ have the capacity to actively destroy $\mathrm{T}$ cells that they target for conjugate formation (44). МФ may express CD95 ligand in high concentration, engaging the $\mathrm{T}$ cell $\mathrm{CD} 95$ receptor in the apoptotic destruction of the $\mathrm{T}$ cell (45).

The $\mathrm{Mh} / \mathrm{Mc}$ balance reveals itself in the polyclonal $\alpha \mathrm{CD} 3$ mediated stimulation of $\mathrm{T}$ cells in our experimental setting: $\mathrm{T}$ cell reactivity depends on the number of $\mathrm{M} \Phi$ and their capacity to up-regulate co-stimulatory molecules $(28,30)$. When ex-

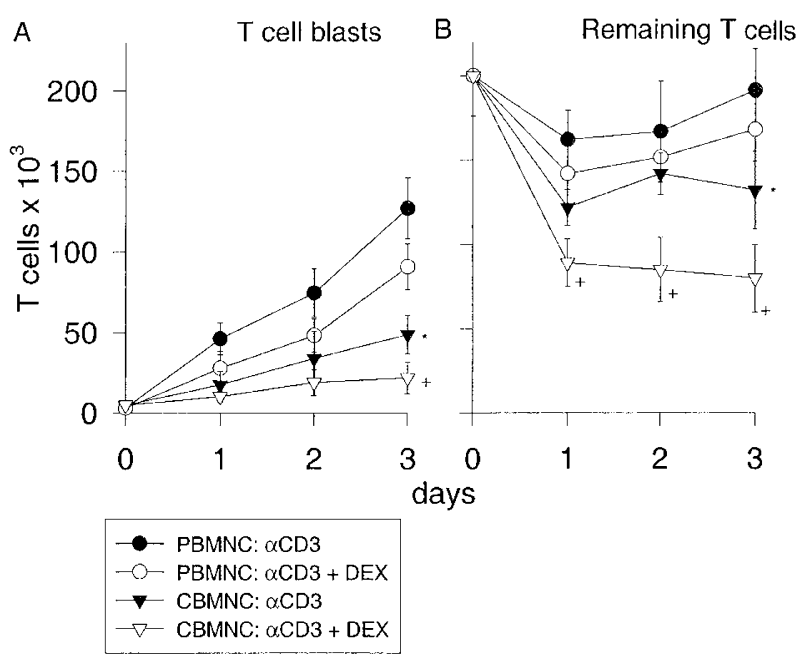

Figure 4. Dexamethasone inhibits $\alpha \mathrm{CD} 3$-mediated $\mathrm{T}$ cell blast transformation and promotes cell death. Unseparated PBMNC of healthy adults (circles) and cord blood (triangles), each containing comparable amounts of $\mathrm{M} \Phi$, were stimulated with $\alpha \mathrm{CD} 3(1 \mu \mathrm{g} / \mathrm{mL})$. Dexamethasone $\left(10^{-6} \mathrm{~mol}\right.$; open symbols) was added before $\alpha \mathrm{CD} 3$. Cells were counted and phenotyped for CD4 and CD8 expression daily. T cell blasts $(A)$ and remaining $\mathrm{T}$ cells $(B)$ were detected. Three experiments are shown (mean $\pm \mathrm{SD}$ ); $* p<0.05$ vs $\alpha \mathrm{CD} 3-$ treated $\mathrm{PBMNC} ;{ }^{+} p<0.05$ dexamethasone-mediated effect $\mathrm{CBMNC} v s$ PBMNC.

posed to $\alpha \mathrm{CD} 3 \mathrm{MAb}$, T cells mount a biphasic immune response, characterized by an initial decline in their number and a subsequent clonal expansion (Figs. 4 and 5). Only the fraction of $\mathrm{T}$ cells that manages to block apoptosis by engagement of CD28 co-stimulatory molecules gets properly activated by $\alpha \mathrm{CD} 3 \mathrm{MAb}$ (39) (Table 1). Other T cells remain anergic or become deleted (39).

The presence of neonatal $\mathrm{M} \Phi$, which were impaired to up-regulate CD80 and CD86 after challenge with $\alpha \mathrm{CD} 3 \mathrm{MAb}$ (16) (Fig. 3), led to a strong decline in remaining T cells and a reduction in proliferating cells (Figs. 4 and 5). Enhancing B7 


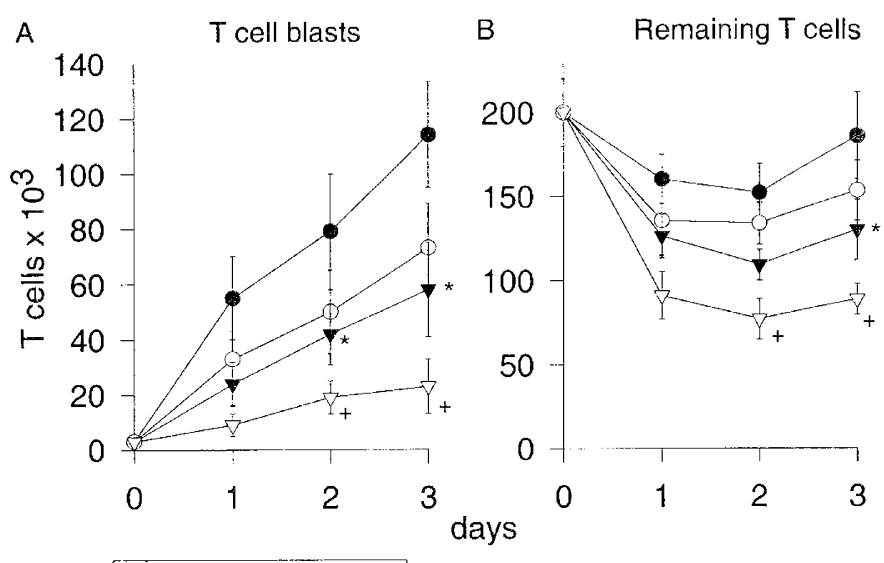

Figure 5. bition of $\alpha \mathrm{CD} 3$-mediated T cell activation than PВМФ. МФ-depleted PBMNC $\left(2 \times 10^{5}\right)$ from one healthy adult donor were co-cultured with РВМФ $(1 \times$ $10^{5}$ ) from a second adult donor (circles) or $1 \times 10^{5} \mathrm{CBM} \Phi$ (triangles) and $\alpha \mathrm{CD} 3(1 \mu \mathrm{g} / \mathrm{mL})$ was added. Two groups received dexamethasone $\left(10^{-6} \mathrm{~mol}\right)$ $2 \mathrm{~h}$ before addition of $\alpha \mathrm{CD} 3$ (open symbols). Samples were taken daily, counted, and phenotyped for CD4 and CD8 expression. T cell blasts $(A)$ and remaining $\mathrm{T}$ cells $(B)$ were depicted. No differences were seen in the nonstimulated groups (data not shown). Four experiments are shown (mean \pm $\mathrm{SD}) ;{ }^{*} p<0.05$ vs $\alpha \mathrm{CD} 3$-treated group with $\mathrm{PBM} \Phi ;{ }^{+} p<0.05$ dexamethasone-mediated effect СВМФ vs РВМФ.

Table 1. CD28 expression on $T$ cells from adult healthy donors after stimulation with $\alpha C D 3$

\begin{tabular}{cccc}
\hline & $\begin{array}{c}\text { Control } \\
(\text { mean } \pm \mathrm{SD})\end{array}$ & $\begin{array}{c}\alpha \mathrm{CD} 3 \\
(\text { mean } \pm \mathrm{SD})\end{array}$ & $\begin{array}{c}\alpha \mathrm{CD} 3+\mathrm{Dexa} \\
(\text { mean } \pm \mathrm{SD})\end{array}$ \\
\hline PВMФ & $75 \pm 22$ & $175 \pm 31^{*}$ & $134 \pm 17^{*}$ \\
$\mathrm{CBM \Phi}$ & $83 \pm 18$ & $117 \pm 10^{*}$ & $80 \pm 11 \dagger$ \\
\hline
\end{tabular}

MФ-depleted PBMNC $\left(2 \times 10^{5}\right)$ from one healthy adult donor were co-cultured with PBMФ $\left(1 \times 10^{5}\right)$ from a second adult donor or CВMФ. Dexamethasone $\left(10^{-6} \mathrm{~mol}\right)$ was added before addition of $\alpha \mathrm{CD} 3(1 \mu \mathrm{g} / \mathrm{mL})$. Samples were phenotyped for CD28 expression after $48 \mathrm{~h}$. Five experiments are shown (mean $\pm \mathrm{SD}$ ). $* p<0.05$ vs corresponding unstimulated control; $\dagger p<0.05$ dexamethasone-mediated inhibition vs РВМФ. No significant differences were seen in the nonstimulated dexamethasone groups (data not shown).

expression either via exchange of a $\mathrm{M} \Phi$ type (Fig. 5) or by addition of IFN- $\gamma$, was associated with increased $\mathrm{T}$ cell blast formation and a decline in the fraction of deleted $\mathrm{T}$ cells $(25,30,39)$. These results underscore the observation that the neonatal $\mathrm{T}$ cell response can be turned on to almost adult-like levels by immunocompetent APC $(14,16)$.

Deficiencies in IFN- $\gamma$ production and effect by neonatal monocytes, which partially are attributed to their immaturity (46), are well documented (47). Marodi (48) identified a deficient cytokine receptor signaling pathway via signal transducer and activator of transcription-1 phosphorylation in response to IFN- $\gamma$, which may help to explain functional consequences. Reduced basal and IFN- $\gamma$-induced HLA-DR expression and up-regulation on СВM $\Phi$ underscore earlier reports (47,49-51). Dexamethasone additionally inhibits IFN- $\gamma$ transcription (52). In accordance with our results, dexa-

methasone inhibits IFN- $\gamma$-induced HLA-DR expression on human monocytic cell lines (50); however, in contrast to CD80 and CD86, our results suggest no significant differences in the dexamethasone-mediated inhibition of HLA-DR up-regulation between РВMФ and СВMФ (Fig. 2C). Whether the drug affects the HLA-DR-mediated antigen-presenting capacity of investigation.

Dexamethasone inhibited the activation-induced upregulation of CD86 on СВMФ and to a lesser extent on PBMФ (Fig. 3). In contrast to Girndt (27), who found no drug-related influence on the CD86 regulation in M $\Phi$ from adults, we used unpurified mononuclear cells for stimulation with IFN- $\gamma$ and cAMP, suggesting additional indirect effects of dexamethasone, e.g. via $\mathrm{T}$ cells.

Although we tried to minimize potentially different effects of dexamethasone on neonatal versus adult $\mathrm{T}$ cells by co-culture, our experimental setup neither excludes drugrelated effects on $\alpha \mathrm{CD} 3$-stimulated T cells, which may influence $\mathrm{M} \Phi$ secondarily, nor rules out allogeneic factors that may influence the $\alpha \mathrm{CD} 3$ reaction in long-term cultures. Memory $\mathrm{T}$ cells, which are characterized by the membrane determinant CD45RO, are virtually absent in cord blood (7) and might account for the increased dexamethasone sensitivity of CBMNC. However, addition of identical amounts of CD45RO cells by co-incubating $\mathrm{T}$ cells of adult donors with $С В M \Phi$ or $Р В M \Phi$ (Fig. 5) indicates a drug-mediated effect on $M \Phi$.

The effects of dexamethasone on CD80 receptor inhibition in adults were found to be transmitted via the cytoplasmic glucocorticoid receptor, because it could be abrogated by the addition of the glucocorticoid receptor antagonist RU38486 (27). The CD80 up-regulation was similarly inhibited by equipotent doses of hydrocortisone and prednisolone (27). Compared with adults, neonatal adrenals are functionally immature, as reflected by decreased neonatal plasma cortisol concentrations (53) and a decreased density of glucocorticoid receptors in the hippocampus (54). The increased sensitivity of CВMФ to dexamethasone therefore may reflect an immunologic compensation for the low levels of glucocorticoids in newborn plasma, so the neonatal immune system may be functionally balanced in vivo.

Here we confirm earlier observations (16) that the newborn macrophage system emphasizes negative rather than positive immune regulation, which may be prudent because in establishing an immune repertoire, the newborn must guard him- or herself most diligently against autoimmune reactions. Our data show that although dexamethasone tilts the $\mathrm{Mh} / \mathrm{Mc}$ balance of both adult and neonatal $\mathrm{M} \Phi$ toward Mc dominance, neonatal M $\Phi$ are significantly more sensitive to this effect of dexamethasone. The drug nearly abrogates the expression of co-stimulatory molecules and strongly enforces Mc activities. Therefore, although the neonatal lung may well respond to dexamethasone, the price that the neonate pays in excessively suppressed immune function may prove prohibitive. 


\section{REFERENCES}

1. Tsukahara H, Watanabe Y, Yasutomi M, Kobata R, Tamura S, Kimura K, Hiraoka M, Mayumi M 1999 Early (4-7 days of age) dexamethasone therapy for prevention of chronic lung disease in preterm infants. Biol Neonate 76:283-290

2. Grier DG, Halliday HL 2003 Corticosteroids in the prevention and management of bronchopulmonary dysplasia. Semin Neonatol 8:83-91

3. Li YH, Brauner A, Jonsson B, Van-der-Ploeg I, Soder O, Holst M, Jensen JS, Lagercrantz H, Tullus K 2001 Inhibition of macrophage proinflammatory cytokine expression by steroids and recombinant IL-10. Biol Neonate 80:124-132

4. Papoff P, Christensen RD, Calhoun DA, Juul SE 2001 Granulocyte colonystimulating factor, granulocyte macrophage colony-stimulating factor and neutrophils in the bronchoalveolar lavage fluid of premature infants with respiratory distress syndrome. Biol Neonate 80:133-141

5. Bessler H, Mendel C, Straussberg R, Gurary N, Aloni D, Sirota L 1999 Effects of dexamethasone on IL-1 $\beta$, IL-6, and TNF- $\alpha$ production by mononuclear cells of newborns and adults. Biol Neonate 75:225-233

6. Bessler H, Kagazanov S, Punsky I, Sirota L 2001 Effect of Dexamethasone on IL-10 and IL-12p40 production in newborns and adults. Biol Neonate 80:262-266

7. Aggarwal S, Gupta A, Nagata S, Gupta S 1997 Programmed cell death (apoptosis) in cord blood lymphocytes. J Clin Immunol 17:63-73

8. Kavelaars A, Zijlstra J, Bakker JM, Van Rees EP, Visser GH, Zegers BJ, Heijnen CJ 1995 Increased dexamethasone sensitivity of neonatal leukocytes: different mechanism of glucocorticoid inhibition of $\mathrm{T}$ cell proliferation of adult and neonatal cells. Eur J Immunol 25:1346-1351

9. Bakker JM, Kavelaars A, Kamphuis PJ, Zijlstra J, van Bel F, Heijnen CJ 2001 Neonatal dexamethasone treatment induces long-lasting changes in T-cell receptor $\mathrm{v} \beta$ repertoire in rats. J Neuroimmunol 112:47-54

10. Parimi PS, Birnrant DJ, Rao LV, Diaz G, Moore JJ 1999 Effect of dexamethasone on lymphocyte subpopulations in premature infants with bronchopulmonary dysplasia. J Perinatol 19:347-351

11. van de Stolpe A, Caldenhoven E, Raaijmakers JA, van der Saag PT, Koenderman L 1993 Glucocorticoid-mediated repression of intracellular adhesion molecule-1 expression in human monocytic and bronchial epithelial cell lines. Am J Respir Cell Mol Biol 8:340-347

12. Irakam A, Miskolci V, Vancurova I, Davidson D 2002 Dose-related inhibition of proinflammatory cytokine release from neutrophils of the newborn by dexamethasone, betamethasone, and hydrocortisone. Biol Neonate 82:98-95

13. Orlikowsky T, Wang ZQ, Dudhane A, Dannecker GE, Niethammer D, Wormser GP, Hoffmann MK, Horowitz HW 2001 Dexamethasone inhibits CD4 T cell deletion mediated by macrophages from human immunodeficiency virus-infected individuals. J Infect Dis 184:1328-1330

14. Ridge JP, Fuchs EJ, Matzinger P 1996 Neonatal tolerance revisited: turning on newborn T cells with dendritic cells. Science 271:1723-1726

15. Hunt DW, Huppertz HI, Jiang HJ, Petty RE 1994 Studies of human cord blood dendritic cells: evidence for functional immaturity. Blood 84:4333-4343

16. Orlikowsky TW, Spring B, Dannecker GE, Niethammer D, Poets CF, Hoffmann MK 2003 Expression and regulation of B7 family molecules on macrophages (MPhi) in preterm and term neonatal cord blood and peripheral blood of adults. Cytometry 53B:40-47

17. Schwartz RH 1992 Costimulation of T lymphocytes: the role of CD28, CTLA-4, and B7/BB1 in interleukin-2 production and immunotherapy. Cell 71:1065-1068

18. Janeway CA Jr, Bottomly K 1994 Signals and signs for lymphocyte responses. Cell $76: 275-285$

19. Kuchroo VK, Das MP, Brown JA, Ranger AM, Zamvil SS, Sobel RA, Weiner HL, Nabavi N, Glimcher LH 1995 B7-1 and B7-2 costimulatory molecules activate differentially the Th1/Th2 developmental pathways: application to autoimmune disease therapy. Cell 80:707-718

20. Nabavi N, Freeman GJ, Gault A, Godfrey D, Nadler LM, Glimcher LH 1992 Signalling through the MHC class II cytoplasmic domain is required for antigen presentation and induces B7 expression. Nature 360:266-268

21. Linsley PS, Greene JL, Brady W, Bajorath J, Ledbetter JA, Peach R 1994 Human B7-1 (CD80) and B7-2 (CD86) bind with similar avidities but distinct kinetics to CD28 and CTLA-4-receptors. Immunity 1:793-797

22. Salomon B, Bluestone JA 2001 Complexities of CD28/B7: CTLA-4 costimulatory pathways in autoimmunity and transplantation. Annu Rev Immunol 19:225-252

23. Azuma M, Ito D, Yagita H, Okumura K, Phillips JH, Lanier LL, Somoza C 1993 B70 antigen is a second ligand for CTLA-4 and CD28. Nature 366:76-79

24. Schmittel A, Scheibenbogen C, Kielholz U 1995 Lipopolysaccharide effectively upregulates B7-1 (CD80) expression and costimulatory function of human monocytes. Scand J Immunol 42:701-704

25. Orlikowsky T, Wang ZQ, Dudhane A, Horowitz HH, Conti B, Hoffmann MK 1997 Two distinct pathways of human macrophage differentiation are mediated by interferon-gamma and interleukin-10. Immunol 91:104-108

26. Hathcock KS, Laszlo G, Pucillo C, Linsley PS, Hodes RJ 1994 Comparative analysis of B7-1 and B7-2 costimulatory ligands: expression and function. J Exp Med 180:631-640

27. Girndt M, Sester U, Kaul H, Hünger F, Köhler H 1998 Glucocorticoids inhibit activation-dependent expression of costimulatory molecule B7-1 in human monocytes. Transplantation 66:370-375
28. Orlikowsky T, Dannecker GE, Wang Z, Horowitz H, Niethammer D, Hoffmann MK 1999 Activation or destruction of T cells via macrophages. Pathobiology 67:298-301

29. Linsley PS, Ledbetter JA 1993 The role of the CD28 receptor during T cell responses to antigen. Annu Rev Immunol 11:191-212

30. Wang ZQ, Orlikowsky T, Dudhane A, Trejo V, Hoffmann MK 1998 Macrophages may activate or destroy $\mathrm{T}$ cells with which they form antigen- or coreceptor-mediated cellular conjugates. Cell Immunol 189:74-82

31. Kümmerle-Deschner JB, Hoffmann MK, Niethammer D, Dannecker GE 1998 Pediatric rheumatology: autoimmune mechanisms and therapeutic strategies. Immunol Today 19:250-253

32. Ding L, Linsley PS, Huang LY, Germain RN, Shevach EM 1993 IL-10 inhibits macrophage costimulatory activity by selectively inhibiting the upregulation of B7 expression. J Immunol 151:1224-1234

33. Wang ZQ, Bapat AS, Rayanade RJ, Dagtas AS, Hoffmann MK 2001 Interleukin-10 induces macrophage apoptosis and expression of CD16 (Fc $\gamma \mathrm{RIII})$ whose engagement blocks the cell death programme and facilitates differentiation. Immunology 102:331337

34. Trinchieri G 1997 Cytokines acting on or secreted by macrophages during intracellular infection (IL-10, IL-12, IFN-gamma). Curr Opin Immunol 9:17-23

35. Wilder RL, Elenkov IJ 1999 Hormonal regulation of tumor necrosis factor-alpha, interleukin-12 and interleukin-10 production by activated macrophages. A diseasemodifying mechanism in rheumatoid arthritis and systemic lupus erythematosus? Ann NY Acad Sci 876:14-31

36. Kataoka Y, Iwasaki T, Kuroiwa T, Seto Y, Iwata N, Hashimoto N, Ogata A, Hamano T, Kakishita E 2001 The role of donor T cells for target organ injuries in acute and chronic graft-versus-host disease. Immunology 103:310-318

37. Wang Z, Horowitz HW, Orlikowsky T, Hahn BI, Trejo V, Bapat AS, Mittler RS, Rayanade RJ, Yang SY, Hoffmann MK 1999 Polyspecific self-reactive antibodies in individuals infected with human immunodeficiency virus facilitate $\mathrm{T}$ cell deletion and inhibit costimulatory accessory cell function. J Infect Dis 180:1072-1079

38. Wang ZQ, Horowitz HW, Orlikowsky T, Dudhane A, Weinstein A, Hoffmann MK 1998 Lymphocyte-reactive autoantibodies in human immunodeficiency virus type 1-infected persons facilitate the deletion of CD8 T cells by macrophages. J Infect Dis 178:404-412

39. Wang ZQ, Bapat AS, Trejo V, Orlikowsky T, Mittler RS, Hoffmann MK 1999 MHC class I molecules on CD4 T cells regulate receptor-mediated activation signals. Cell Immunol 193:108-114

40. Sperling AI, Auger JA, Ehst BD, Rulifson IC, Thompson CB, Bluestone JA 1996 CD28/B7 interactions deliver a unique signal to naive $\mathrm{T}$ cells that regulates cell survival but not early proliferation. J Immunol 157:3909-3917

41. Hurtado JC, Kim YJ, Kwon BS 1997 Signals through 4-1BB are costimulatory to previously activated splenic $\mathrm{T}$ cells and inhibit activation-induced cell death. J Immunol 158:2600-2609

42. Orlikowsky T, Wang ZQ, Dudhane A, Horowitz HW, Riethmuller G, Hoffmann MK 1997 Cytotoxic monocytes in the blood of HIV type 1-infected subjects destroy targeted T cells in a CD95-dependent fashion. AIDS Res Hum Retroviruses 13:953960

43. Wang Z, Horowitz HW, Orlikowsky T, Hahn BI, Trejo V, Bapat AS, Mittler RS, Rayanade RJ, Yang SY, Hoffmann MK 1999 Polyspecific self-reactive antibodies in individuals infected with human immunodeficiency virus facilitate $\mathrm{T}$ cell deletion and inhibit costimulatory accessory cell function. J Infect Dis 180:1072-1079

44. Dudhane A, Conti B, Orlikowsky T, Wang ZQ, Mangla N, Gupta A, Wormser GP, Hoffmann MK 1996 Monocytes in HIV type 1-infected individuals lose expression of costimulatory B7 molecules and acquire cytotoxic activity. AIDS Res Hum Retroviruses 12:885-892

45. Kiener PA, Davis PM, Rankin BM, Klebanoff SJ, Ledbetter JA, Starling GC, Liles WC 1997 Human monocytic cells contain high levels of intracellular Fas ligand: rapid release following cellular activation. J Immunol 159:1594-1598

46. Stiehm ER, Sztein MB, Steeg PS, Mann D, Newland C, Blaese M, Oppenheim JJ 1984 Deficient DR antigen expression on human cord blood monocytes: reversal with lymphokines. Clin Immunol Immunopathol 30:430-436

47. Taylor S, Bryson YJ 1985 Impaired production of gamma-interferon by newborn cells in vitro is due to a functionally immature macrophage. J Immunol 134:1493-1497

48. Marodi L 2002 Deficient interferon-gamma receptor-mediated signaling in neonatal macrophages. Acta Paediatr Suppl 91:117-119

49. Birle A, Nebe TC, Gessler P 2003 Age-related low expression of HLA-DR molecules on monocytes of term and preterm newborns with and without signs of infection. J Perinatol 23:294-299

50. Schwiebert LM, Schleimer RP, Radka SF, Ono SJ 1995 Modulation of MHC class II expression in human cells by dexamethasone. Cell Immunol 165:12-19

51. Wakasugi N, Virelizier JL 1985 Defective IFN- $\gamma$ production in the human neonate. I. Dysregulation rather than intrinsic abnormality. J Immunol 134:167-171

52. Arya SK, Wong-Staal F, Gallo RC 1984 Dexamethasone-mediated inhibition of human $\mathrm{T}$ cell growth factor and gamma-interferon messenger RNA. J Immunol 133:273-276

53. Munck A, Guyre PM 1990 Psychoneuroendocrinology, 2nd Ed. Acad Press, San Diego, pp 447-461

54. Rosenfeld P, Van Eekelen JA, Levine S, de Kloet ER 1993 Ontogeny of glucocorticoid receptors in the brain. Cell Mol Neurobiol 13:261-277 